\title{
FORMATION OF GEOGRAPHY AS A SCIENCE IN UZBEKISTAN IN THE XX CENTURY
}

\author{
Tolibov Nurbek \\ $\mathrm{PhD}$ researcher of department of Historical sources \\ and archive studies of National University of Uzbekistan
}

Article DOI: https://doi.org/10.36713/epra4340

\begin{abstract}
From ancient times the scientists of Central Asia have made a great contribution to the development of geography. In the twentieth century, Uzbekistan experienced its own stage of development. This article analyzes the most important research conducted in the twentieth century for the development of geography in Uzbekistan, the work on the creation of geographical atlases and maps, as well as geographical dictionaries in the country.
\end{abstract}

\section{DISCUSSION}

Early geographical knowledge was accumulated during the aspirations of primitive people to explore the place where they lived, to find and describe places that are suitable for living, rich in natural resources. Geography is a Greek word that means "ge" - earth, "o" - connecting, "grafo" - to describe, draw, that is, the image of the Earth. The word geography was first introduced to science by the Greek scientist Eratosthenes in the third century BC in his work "Geography". Our compatriot, the great scholar Muhammad Musa al-Khwarizmi also wrote a work entitled "Kitab surat ul-arz" in the IX century. The name of this work, translated from Arabic into Uzbek, means "a book about the image of the Earth". The world's first model of the Earth - the globe - was invented in the IX century by our great scientist Abu Rayhan Beruni [1:5].

In the territory of Uzbekistan, geography was taught in madrassas in the XVIII-XIX centuries, in the $80 \mathrm{~s}$ of the XIX century in Russian-style schools, in 1900 in new method schools. Since the 1990s, the first textbook on geography - "Words from science about the earth" has been published in Uzbek. In the 1880s, Haji Yusuf Hayati (1842 1924) created a geographical globe. In 1905, the "Map of Turkestan and Adjacent Countries" was published for the new method schools.

In the twentieth century, geography education developed in Turkestan. M. Behbudi's "Brief General Geography" (1902), "Introduction to Population Geography" (1903), Fatih Karim's "Geography" (1914), Muhammad Aminkarimi's "Geographical Mathematics" (1914), Munavvarqori
Abdurashidkhan oglu's "Earth" (1915), N.I. Balashov's textbook "Geography of Turkestan" (1922) was published. From 1930 to 1990, the natural and economic geography of Uzbekistan was taught in general education schools only on the basis of textbooks and manuals written by local authors. Textbooks on the methods of teaching geography have been published. O. on geography. Ibragimov's "Terms of Geography" (1935), M. Bektemirov and Saidrasulov's "Short Russian-Uzbek Dictionary of Geographical Terms" (1940), N, Dolimov's "Short Russian-Uzbek Dictionary of Geographical Terms" (1953), H.H. Hasanov's "Dictionary of Geographical Terms" (1964), S. Qoraev, P. Gulomov, R. Rakhimbekov's "Explanatory Dictionary of Geographical Terms and Concepts" (1979) was created. Higher education in geography also developed significantly during this period. Geography faculties were opened in state universities and pedagogical institutes. Textbooks and manuals on Geography for high schools have been translated into Uzbek and new ones have been written. A new state standard of geography education, curricula have been developed. Several new textbooks, manuals, a glossary of geographical terms, and maps have been created.

By compiling general geographical maps of Central Asia and Uzbekistan, the geographer N.L. Korzhenevsky was engaged. The geobotanical map, compiled by Korovin in 1933 and attached to the monograph "Plants of Central Asia and Kazakhstan", has gained significant biogeographic, ecological and geographical significance. In the $1920 \mathrm{~s}$, R. with cartography. I. Abolin, I. in the 1930s and 1950s. I. Granitov was engaged. In 1940-50s, geographically 
important soil and soil-climatic maps of Uzbekistan were published. In the 1960s, the Uz-Giprozem Institute published more than 10 agricultural maps and landscape maps at scales of 1: 1000000 and 1: 1500000 for production and educational purposes. In those years, educational maps of natural and local lore of all regions of Uzbekistan were published (T.M Mirzaliev). The importance of scientific conferences and published books in the development of geography in the former Soviet Union was significant. In particular, scientific conferences on natural geography and economic geographical zoning of the Central Asian and Kazakh republics were held in 1959, 1961, 1967 and 1971, and on population problems in 1965 and 1972. Urbanization processes have also been discussed in prestigious scientific seminars (1973 and 1975). Z.M. Akramov, M.K. Karakhanov and O.B. Ota-Mirzaev played an important role in organizing such events. In the eighties, scientific and practical conferences on various problems of economic and social geography were held in Samarkand, Namangan, Fergana, Angren and other cities. Geographical scientific monographs on the Republic of Uzbekistan were published in 1950, 1953, 1956, 1963 and 1982. Scientists of the Faculty of Geography of Tashkent State University took an active part in writing these books. Information about the independent Republic of Uzbekistan is also contained in the books of E. Ahmedov. At the same time, textbooks on economic geography of Uzbekistan have been written for secondary and higher schools. The textbook on primary schools was co-authored by N.G. Sapenko and N.V. Smirnov.

Later this textbook was written by professor Z.M. Akramov in collaboration with P. Musaev, parents Musaevs and A.S. Soliev and R. Kurbanniyozov. The textbook of world economic and political geography was created by A. Kayumov, I. Safarov[1:114].

Recently, due to the need to develop the national economy, the scope of geographical research has expanded, geographical research, their methods are improving and increasing in order to study the natural conditions of Central Asia for practical purposes, as well as to identify and evaluate new natural resources. By this time, continuous research began to be carried out, along with scientific travel research. In particular, the use of images taken from space in the process of geographical research has become widespread. Much has been done to study the nature and cultural landscapes of the region. New scientific directions in Central Asian geography, such as reclamation geography, recreational geography, anthropogenic landscape, tourism geography, began to develop [3:25-26].

Scientific centers of cartography of Uzbekistan are the Department of Geodesy and Cartography of the National University of Uzbekistan named after Mirzo Ulugbek and the Department of Geography of the Academy of Sciences of Uzbekistan within the Institute of Seismology. At the initiative and with the participation of cartographers of Tashkent State University (T.M. Mirzaliev, E.G. Brodsky, A.E. Egamberdiev, L.M. Kuzibaeva, L.G. Solieva) in 1981 the first educational atlas of Uzbekistan was published in Russian and Uzbek languages. was found.

In 1981-2000, the Department of Geography published more than 70 academic atlases of Uzbekistan, atlases of Tashkent, cotton and medicalgeographical atlases, album atlases "Turkistan - our common home", nature protection, desertification and landscape maps in addition to the ecological map of Uzbekistan. L.X. Gulomova on the use of space methods in cartographic research, M. Asomov, Sh. Buzrukov, A. Bozorboev, J. Koraboev, T. Karabaev are conducting research in various areas and topics of cartography [4:35].

"No country in the world today, including the Republic of Uzbekistan, is a separate region" [5:163]. These countries are part of certain geographical and political systems of world economic relations. From the time of the emergence of humanity, as society has evolved, the relationship between man and nature has become more complex. As a result, the ancient and ever-evolving science of geography is expanding its place and importance. In particular, problems of economic and social geography are taught at the faculties of economics, philosophy, history and jurisprudence of the National University of Uzbekistan, Tashkent State Pedagogical University and all faculties of many universities in the regions of the country [6:11].

The socio-economic development of any country depends in many ways on its natural conditions and natural resources. Together, they determine the natural resource potential of the region, which consists of the natural resources that are used, as well as the opportunities and resources that can be used.

\section{LIST OF USED LITERATURE}

1. Rafiqov G., Vahobov H., Qayumov A., Azimov Sh. Applied geography. -Tashkent: Sharq, 2010. B. 5

2. Soliev A., Mahamadaliev R. Fundamentals of economic and social geography. - Tashkent, 2005.

3. Baratov P., Mamatqulov M., Rafiqov A. Natural geography of Central Asia. - Tashkent: «Teacher», 2002.

4. Countries and Peoples. Soviet Union. - Moscow "Thought", 1984.

5. Bahritdinov B.A., Zokirova S.A., Abdurahimova G.A., A'zam S.E. Socio-economic geography of the world. - Toshkent, 2008.

6. Soliev A. Geography of Uzbekistan. - Tashkent: "Universitet", 2014. 